\title{
Intratumoral localization and activity of $17 \beta$-hydroxysteroid dehydrogenase type 1 in non-small cell lung cancer: a potent prognostic factor
}

Mohit K Verma ${ }^{1,6}$, Yasuhiro Miki ${ }^{1,2}$, Keiko Abe ${ }^{1}$, Takashi Suzuki ${ }^{1,3}$, Hiromichi Niikawa ${ }^{4}$, Satoshi Suzuki ${ }^{5}$, Takashi Kondo ${ }^{4}$ and Hironobu Sasano ${ }^{1 *}$

\begin{abstract}
Background: Estrogens were recently demonstrated to be synthesized in non-small cell lung carcinomas (NSCLCs) via aromatase activity and aromatase inhibitor (Al) did suppressed estrogen receptor (ER) positive NSCLC growth. However, other enzymes involved in intratumoral production and metabolism of estrogens, i.e. 17 $\beta$-hydroxysteroid dehydrogenases (i.e. 17ßHSD1 and 17ßHSD2) and others have not been studied. Therefore, in this study, we examined the clinical/ biological significance of 17ß-hydroxysteroid dehydrogenases in NSCLCS.

Methodology: Archival materials obtained from 103 NSCLC patients were immunohistochemically evaluated using anti-173HSD1 and anti-173HSD2 antibodies. The findings of immunohistochemistry were then correlated with intratumoral estrone (E1) and estradiol (E2) concentration, clinicopathological factors and overall survival of the patients. We further employed NSCLC cell lines, A549 and LK87 to study the functional significance of 17BHSD1, in vitro.

Results: A higher 17BHSD1 immunoreactivity tended to be positively associated with aromatase $(p=0.057)$ and tumor stage $(p=0.055)$ whereas a higher $17 \beta \mathrm{HSD} 2$ immunoreactivity was positively associated with a squamous cell and adenosquamous cell carcinomas subtypes $(p=0.031)$, tumor stage $(p=0.004)$, T factor of TNM classification $(p=0.010)$, maximum tumor diameter $(p=0.002)$ and tended to be associated with $N$ factor of TMN classification $(p=0.065)$. A higher $17 \beta \mathrm{HSD} 1$ immunoreactivity was also significantly associated with lower intratumoral E1 concentration $(p=0.040)$ and a higher intratumoral E2/E1 concentration ratio $(p=0.028)$. On the other hand a higher $17 \beta H S D 2$ immunoreactivity was significantly associated with higher intratumoral E1 concentration $(p=0.035)$. Results of multivariate regression analysis demonstrated an increased 17ßHSD1 immunoreactivity in tumor cells as an independent negative prognostic factor $(H R=2.83, p=0.007)$. E1 treatment in $17 \beta H S D 1$ positive NSCLC cells, A549 and LK87, resulted in E2 production $(p<0.0001)$ and enhanced cell proliferation, which was abrogated effectively by $17 \beta H S D 1$ siRNA knockdown $(p<0.0001)$. In addition, aromatase inhibitor treatment resulted in 17ßHSD1 up regulation in both $\mathrm{A} 549$ and LK87 cells.
\end{abstract}

Conclusion: Results of our present study suggest that 17BHSD1 may be considered an important prognostic factor in NSCLC patients and targeting 17ßHSD1 activity may further improve the clinical response in estrogen responsive NSCLC patients.

Keywords: Lung cancer, Intratumoral estrogens, 17ß-hydroxysteroid dehydrogenase, Targeted therapy

\footnotetext{
* Correspondence: hsasano@patholo2.med.tohoku.ac.jp

'Department of Pathology, Tohoku University Graduate School of Medicine,

Sendai, Japan

Full list of author information is available at the end of the article
}

\section{Ciomed Central}

(c) 2013 Verma et al.; licensee BioMed Central Ltd. This is an Open Access article distributed under the terms of the Creative Commons Attribution License (http://creativecommons.org/licenses/by/2.0), which permits unrestricted use, distribution, and reproduction in any medium, provided the original work is properly cited. 


\section{Introduction}

Lung cancer is the leading cause of cancer mortality worldwide [1]. Tobacco smoking still remains its prime cause among both men and women [2] but recent studies have also demonstrated that estrogens may contribute to the cell proliferation of some non-small cell lung carcinoma (NSCLC) cells [3]. Estrogens exert their effects via estrogen receptors (ERs) which are reported to be expressed very frequently in human NSCLCs of either gender, especially ER $\beta$ [4]. Both genomic and nongenomic actions of estradiol (E2) via ER $\beta$ have been reported in NSCLC cells; which result in tumor progression [5]. Therefore, at least some NSCLC are reasonably considered novel estrogen dependent neoplasms.

Male NSCLC patients with a high free E2 serum levels had significantly worse clinical outcome compared to those with lower E2 levels [6]. However, a frequent aromatase expression [7] and the ability of local production of estrogens via aromatase in estrogen dependent lung carcinoma cells have also been reported [8]. Due to the frequent expression of aromatase in NSCLC patients a phase II randomized trial of aromatase inhibitor (anastrozole) and ER blocker (fulvestrant) as consolidation therapy in postmenopausal women with advanced NSCLC was scheduled [9]. However, it is important to note that aromatase is not the only estrogen producing enzyme and other enzymes involved with intratumoral production and metabolism of estrogens, i.e. 17 $\beta$ hydroxysteroid dehydrogenases (i.e. 17ßHSD1 and 17ßHSD2), steroid sulphatse (STS), estrone sulfotransferase (EST) could also be involved in modulation of intratumoral estrogens levels in NSCLCs. However, there have been no studies published on possible roles of $17 \beta$ HSDs, STS and EST in NSCLC patients.

$17 \beta H S D 1$ catalyzes primarily the reduction of estrone (E1) to E2, whereas $17 \beta \mathrm{HSD} 2$ catalyzes primarily the oxidation of E2 to E1, and together they modulate the overall tissue levels of bioactive E2 in peripheral tissues including breast cancer [10]. An inhibitory potential of various novel $17 \beta \mathrm{HSD} 1$ inhibitors have been demonstrated for the treatment of estrogen-dependent diseases [11-13].

Based upon the reported findings above, we tentatively hypothesized that $17 \beta$ HSDs pathway may play important roles in lung tumor progression via intratumoral estrogens production and regulation. Therefore, in this study, we first evaluated the status of both $17 \beta$ HSD1 and $17 \beta$ HSD2 in 103 NSCLC patients using immunohistochemistry (IHC). We then studied the correlation of the findings with clinicopathological variables, intratumoral E1 and/or intratumoral E2 tissue concentrations and overall survival in individual patients. The activity and regulation of 17ßHSD1 was further examined in NSCLC cell lines i.e. A549 and LK87.

\section{Materials and methods Patients}

103 NSCLC cases were retrieved from surgical pathology files of Department of Pathology, Tohoku University Hospital who underwent surgery from 1993 to 2003. Neither anti-EGFR nor anti-hormonal therapy was administered to any of the patients examined prior to surgery. Informed consent was obtained from each patient before surgery. Research protocols for this study were approved by the Ethics Committee at Tohoku University School of Medicine (Approval No. 2009-500).

\section{Immunohistochemistry}

Serial tissue sections of $3 \mu \mathrm{m}$ thickness fixed in $10 \%$ formaldehyde solution and embedded in paraffin were used for both hematoxylin-eosin staining and immunohistochemistry using labeled streptavidin biotin method. The primary antibodies used in this study are given as Additional file 1 [14]. Positive controls were invasive ductal carcinoma of the breast for ER $\alpha$, adenocarcinoma of the prostate for ER $\beta$, tonsil for Ki67 and human full term placenta for aromatase, $17 \beta \mathrm{HSD} 1$ and $17 \beta \mathrm{HSD} 2$. As a negative control, normal mouse or rabbit IgG was used instead of the primary antibodies and no specific immunoreactivity was detected in these sections (data not shown). Immunoreactivity of ER $\alpha$, ER $\beta$, Ki-67/MIB1 and steroidogenic enzymes i.e. aromatase, $17 \beta \mathrm{HSD} 1$ and $17 \beta \mathrm{HSD} 2$ was counted among 1000 cells per case at hot spots and was determined as "positive" if immunereactivity was detected in more than $10 \%$ of cells, as previously described [15-17]. Based on the relative immunointensity of $17 \beta \mathrm{HSD} 1$ and/or $17 \beta \mathrm{HSD} 2$ in cytoplasm of the patients, the cases were classified as low (negative or weakly positive) and high (moderately/strongly positive), also according to the previous report [18]. The evaluation of immunohistochemical stains was done independently by two of the authors (M.K.V. and T.S.) that were blinded to the results for each antibody.

\section{Liquid chromatography/electrospray tandem mass spectrometry}

Among 103 NSCLC patients, 48 paired frozen specimen of lung carcinomas and corresponding non-neoplastic lung tissues were available for liquid chromatography/ electrospray tandem mass spectrometry for measurement of intratumoral E1 concentrations as previously reported $[17,19]$. We previously reported intratumoral E2 concentrations in these 48 patients [19]. The detailed methods of analyzing the intratumoral estrogens concentrations were also described in the report above.

\section{Cell culture and chemicals}

Human NSCLC cell lines i.e. A549 and LK87 were provided by Institute of Development, Aging and Cancer, Tohoku University. Both of the cell lines were lung 
adenocarcinomas of male origin i.e. A549 (ATCC data sheet) and LK87 [20,21]. The cells were cultured in RPMI 1640 (Sigma-Aldrich) with $10 \%$ fetal bovine serum (Nichirei Co. Ltd.). Cells were incubated at $37^{\circ} \mathrm{C}$ in a humidified atmosphere containing $5 \% \mathrm{CO}_{2}$. E1, E2 and testosterone were commercially obtained from Sigma-Aldrich.

\section{Quantitative RT-PCR}

Total RNA was extracted using TRIzol reagent (Invitrogen Life Technologies) and cDNA was synthesized using a QuantiTect reverse transcription kit (Qiagen). Quantitative real-time PCR was carried out using the LightCycler System and FastStart DNA Master SYBR Green I (Roche Diagnostics). Ribosomal protein L 13a (RPL13A) was also used as an internal standard. The primer sequences used in this study are given as Additional file 2.

\section{ELISA assay}

Cells were serum starved for 24 hours in a 24-well plate and then treated with steroids for 24 hours. Supernatant media was collected and evaluated for estrogen production using Estradiol EIA Kit (Cayman Chemical Company) according to the manufacturer's protocol. An appropriate standard curve was plotted and the concentration of estradiol was determined.

\section{siRNA transfections}

One scramble siRNA as a control and two 17ßHSD1 specific siRNA were purchased from Sigma-Aldrich. The sense and antisense sequences of the two $17 \beta-$ HSD 1 siRNA, as described in the previous report [22] are given as Additional file 3. $200 \mathrm{nM}$ of either $17 \beta \mathrm{HSD} 1$ siRNA 1 or 2 was transfected in NSCLC cell lines, i.e. A549 and LK87 cells, using G-fectin kit (Genolution Pharmaceuticals, Inc.) according to manufacturer's protocol. Cells were harvested after 72 hours of siRNA transfections and evaluated for 17 $\beta$ HSD1 expression and/or activity.

\section{Cell proliferation assay}

Cells were serum starved for 24 hours in a 96-well plate and then treated with test compounds and/or siRNA transfections for 72 hours. Then cells were harvested and evaluated for cell proliferation using WST-8 method (Cell Counting Kit-8; DOJINDO Laboratories). Optical densities (OD, $450 \mathrm{~nm}$ ) were obtained with a microplate spectrophotometry (Model680, Bio-Rad Laboratories).

\section{Immunoblotting}

Cells were serum starved for 24 hours in a 6 well plate and then treated with test compounds and/or siRNA transfections for an adequate length of time. 10 micrograms of the proteins from the cells were subjected to
SDS-PAGE (10\% acrylamide gel, SuperSep ${ }^{\mathrm{Tm}}$ Ace: Wako). The primary antibodies used were anti-17ßHSD1 (1:1000; clone 2E5; Abnova) and anti- $\beta$-actin (1:1000; clone AC-15, Sigma-Aldrich). These antibody-protein complexes on the blots were detected using ECL-plus Western blotting detection reagents (GE Healthcare) using LAS-1000 cooled CCD-camera chemiluminescent image analyzer (Fuji Photo Film Co., Ltd.).

\section{Statistical analysis}

For the statistical analysis in this study, we used STATVIEW version 5.0 (J software, SAS Institute Inc., USA). Statistical analyses used Fisher's PLSD test, Scheffe's F test, Bonferroni/Dunn test, Kaplan-Meier test, Logrank (Mantel-Cox) test and Student's $t$ test. A $p$-value less than 0.05 were considered to be significant.

\section{Results}

Immunohistochemistry of $17 \beta$ HSD1 and $17 \beta$ HSD 2 in NSCLC patients

Clinicopathological characteristics of the 103 NSCLC patients examined were summarized in Tables 1 and 2 . $17 \beta$ HSD1 and 17 $\beta$ HSD2 immunoreactivity was detected in the cytoplasm of $85 \%$ and $95 \%$ of the patients, respectively (Table 1, Figure 1). A high 17ßHSD1 immunoreactivity tended to be positively associated with tumor stage $(\mathrm{p}=0.055)$ and aromatase $(\mathrm{p}=0.057)$, (Table 2$)$. A high $17 \beta$ HSD2 immunoreactivity status was positively associated with squamous cell and adenosquamous cell carcinomas subtypes $(p=0.031)$, tumor stage $(\mathrm{p}=0.004), \mathrm{T}$ factor of TNM classification ( $p=0.010)$, maximum tumor diameter $(p=0.002)$ and tended to be associated with $\mathrm{N}$ factor of TMN classification $(p=0.065)$ (Table 2). In addition, among $17 \beta$ HSD1 and 17ßHSD2 double positive patients (85 cases), a high status of $17 \beta$ HSD1 was significantly associated with that of $17 \beta \mathrm{HSD} 2(p=0.014)$.

\section{Association of $17 \beta \mathrm{HSD} 1$ and $17 \beta \mathrm{HSD} 2$ with intratumoral tissue Estrone and Estradiol concentrations in NSCLC patients}

The median with minimum-maximum value of tissue concentration of E1 and E2 in lung cancer tissues was $170.5 \mathrm{pg} / \mathrm{g}(9.2-979.88)$ and $20.35 \mathrm{pg} / \mathrm{g}(4.2-233.88)$ in this study. Thirty-four (71\%) of 48 NSCLC cases demonstrated higher E1 tissue concentration in carcinoma tissues than the corresponding non-neoplastic lung tissues from the same patients, and these intratumoral E1 concentrations tended to be higher than those detected in their corresponding non-neoplastic lung tissues [148.6 (12.7-837.87) pg/g], $(p=0.061)$, (Figure 2a). Tissue concentrations of E1 in men were significantly higher than those detected in postmenopausal women both in NSCLC (199.38 (104.43-979.88) pg/g in men and 141.11 (9.2-359.5) $\mathrm{pg} / \mathrm{g}$ in postmenopausal women, $p=0.006)$, 


\begin{tabular}{|c|c|}
\hline Clinicopathologic characteristics & No. of cases (\%) \\
\hline Age & $45-82$ years \\
\hline \multicolumn{2}{|l|}{ Sex } \\
\hline Male & $62(60.2 \%)$ \\
\hline Female & 41 (39.8\%) \\
\hline \multicolumn{2}{|l|}{ Histology } \\
\hline Adenocarcinoma & 77 (74.7\%) \\
\hline Squamous cell carcinoma & $23(22.3 \%)$ \\
\hline Adenosquamous cell carcinoma & $3(2.9 \%)$ \\
\hline \multicolumn{2}{|l|}{ Tumor size } \\
\hline T1 & 47 (45.6\%) \\
\hline T2 & $45(43.7 \%)$ \\
\hline T3 & $5(4.8 \%)$ \\
\hline T4 & $6(5.8 \%)$ \\
\hline \multicolumn{2}{|l|}{ Lymph node metastases } \\
\hline No & $78(75.7 \%)$ \\
\hline N1 & $9(8.7 \%)$ \\
\hline N2 & $16(15.5 \%)$ \\
\hline \multicolumn{2}{|l|}{ Distance metastasis } \\
\hline MO & $99(96.1 \%)$ \\
\hline M1 & $4(3.8 \%)$ \\
\hline \multicolumn{2}{|l|}{$17 \beta$ HSDs } \\
\hline 17ßHSD1 & $88(85.4 \%)$ \\
\hline $17 \beta \mathrm{HSD} 2$ & 98 (95.1\%) \\
\hline ERa & $24(23.3 \%)$ \\
\hline ER $\beta$ & $92(89.3 \%)$ \\
\hline Aromatase & $86(83.4 \%)$ \\
\hline
\end{tabular}

(Figure 2b) and non-neoplastic lung tissues (173.59 (72.44-837.87) pg/g in men and 85.68 (12.7-281.2) pg/g in postmenopausal women, $p<0.0001)$. Tissue E1 concentrations were significantly lower in NSCLC with a high $17 \beta$ HSD1 status than that in patients with a low/ negative $17 \beta$ HSD1 status (151.57 (9.2-367.25) $\mathrm{pg} / \mathrm{g}$ in high $17 \beta$ HSD1 status and 197.08 (97.5-979.88) $\mathrm{pg} / \mathrm{g}$ in low/negative 17ßHSD1 status, $p=0.040$ ) (Figure 2c). Tissue E1 concentrations were, however, significantly higher in NSCLC with a high 17ßHSD2 status than that in patients with a low or negative 17ßHSD2 status (194.28 (58.64-527.7) pg/g in high 17ßHSD2 status and $163.89(9.2-979.88) \mathrm{pg} / \mathrm{g}$ in low/negative 17ßHSD2 status, $p=0.035$ ) (Figure. $2(\mathrm{~d})$ ). There were no significant differences in intratumoral E2 concentration according to $17 \beta$ HSD1 status $(p=0.613)$ and/or 17ßHSD2 status $(p=0.177)$ (data not shown) but a higher intratumoral E2/ E1 ratio was significantly associated with a high $17 \beta$ HSD1 status than that in those with a low/negative 17ßHSD1 status $(p=0.028)$ (Figure 2e). No significant differences were detected in intratumoral E2/ E1 ratio between a high $17 \beta$ HSD2 status and that in patients with a low/negative $17 \beta$ HSD1 status $(p=0.404)$, (Figure $2 \mathrm{f})$.

\section{Association of $17 \beta$ HSD1 and 17 $\beta$ HSD2 with clinical outcome of NSCLC patients}

$17 \beta$ HSD1 negative cases were significantly associated with better overall survival when compared to 17ßHSD1 positive ones $(p=0.012)$, (Figure $2 \mathrm{~g}$ ). $17 \beta$ HSD2 negative cases were significantly associated with poorer overall survival when compared to $17 \beta$ HSD2 positive patients $(p=0.021)$, (Figure 2h) but cases with both higher $17 \beta$ HSD1 and 17ßHSD2 status when compared to those with both low status were positively associated with worse overall survival in NSCLC patient $(p=0.012)$ and $(p=0.021)$ respectively (Figure $2 \mathrm{~g}, \mathrm{~h})$. A subsequent multivariate regression analysis, however, demonstrated that only high $17 \beta \mathrm{HSD} 1$ status $(\mathrm{HR}=2.83, p=0.007)$, sex $(\mathrm{HR}=2.22, p=0.039)$, tumor stage $(\mathrm{HR}=3.97, p=0.041)$, pT status $(p=0.042),(\mathrm{HR}=2.83, p=0.007)$ and maximum tumor diameter $(\mathrm{HR}=6.53, p=0.001)$ turned out independent prognostic factors (Table 3 ).

\section{Expression of $17 \beta H S D 1$ and $17 \beta H S D 2$ in NSCLC cell lines}

We employed NSCLC cell lines A549 and LK87 expressing both aromatase and ER $\beta$ [23]. Quantitative RT-PCR analysis demonstrated that both A549 and LK87 cells express $17 \beta \mathrm{HSD} 1$ and 17ßHSD2 mRNA (Figure 3a,b). The amounts of $17 \beta$ HSD1 mRNA expression was significantly higher than that of $17 \beta$ HSD 2 in both of the NSCLC cell lines examined $(p<0.0001)$. However, the amounts of $17 \beta \mathrm{HSD} 2$ mRNA expression was significantly higher in NSCLC cells than in breast carcinoma cells i.e. MCF-7, $(p<0.0001)$.

\section{Targeting $17 \beta \mathrm{HSD} 1$ activity in NSCLC cells}

A 24-hour treatment with 100nM E1 resulted in a significantly higher E2 production (5-fold) when compared to treatment with $100 \mathrm{nM}$ testosterone in both A549 and LK87 cells ( $p=<0.0001)$, (Figure 3c). In addition, a 72 hour treatment with aromatase inhibitor (letrozole) resulted in up regulation of $17 \beta \mathrm{HSD} 1$ expression (Figure $3 \mathrm{~d}$ ). Two $17 \beta$ HSD1 specific siRNA and a negative control of scramble siRNA were selected and used according to a previous report [22] in order to effectively knock down the expression of $17 \beta$ HSD1 in these NSCLC cells. A 72 hour treatment with $17 \beta \mathrm{HSD} 1$ siRNA 2 significantly lowered endogenous 17ßHSD1 expression in both A549 and LK87 cells (Figure 3e). In addition, a 72 hour E1 treatment increased cell proliferation in both of the NSCLC cell lines examined $(p=<0.0001)$, which was also significantly 
Table 2 Association between clinicopathological variables and 17 $\beta$ HSD1/ 17 $\beta$ HSD2 status in 103 NSCLC patients

\begin{tabular}{|c|c|c|c|c|c|c|c|}
\hline \multicolumn{2}{|c|}{103 cases } & \multicolumn{2}{|c|}{$17 \beta$ HSD1 } & \multirow[b]{2}{*}{$\mathbf{P}$} & \multicolumn{3}{|c|}{$17 \beta$ HSD2 } \\
\hline & & High $n=51$ & Low/Negative $n=52$ & & High $n=54$ & Low/Negative $n=49$ & $\mathbf{P}$ \\
\hline \multirow[t]{2}{*}{ SEX } & Male & 31 & 31 & & 36 & 26 & \\
\hline & Female & 20 & 21 & 0.903 & 18 & 23 & 0.158 \\
\hline \multirow[t]{3}{*}{ Histology } & Adeno & 38 & 39 & & 35 & 42 & \\
\hline & SCC & 11 & 12 & & 16 & 7 & \\
\hline & Adeno squamous & 2 & 1 & 0.826 & 3 & 0 & 0.031 \\
\hline \multirow[t]{4}{*}{ Stage } & I & 28 & 40 & & 27 & 41 & \\
\hline & $\|$ & 7 & 2 & & 7 & 2 & \\
\hline & III & 15 & 8 & & 18 & 5 & \\
\hline & IV & 1 & 2 & 0.055 & 2 & 1 & 0.004 \\
\hline \multirow[t]{4}{*}{ pT } & $\mathrm{p} T 1$ & 20 & 27 & & 18 & 29 & \\
\hline & pT2 & 25 & 20 & & 26 & 19 & \\
\hline & pT3 & 3 & 2 & & 4 & 1 & \\
\hline & pT4 & 3 & 4 & 0.617 & 6 & 0 & 0.010 \\
\hline \multirow[t]{3}{*}{$\mathrm{pN}$} & pNO & 34 & 44 & & 36 & 42 & \\
\hline & $\mathrm{pN1}$ & 6 & 3 & & 7 & 2 & \\
\hline & $\mathrm{pN} 2$ & 11 & 5 & 0.100 & 11 & 5 & 0.065 \\
\hline \multirow[t]{2}{*}{ pM } & $\mathrm{pMO}$ & 50 & 49 & & 52 & 47 & \\
\hline & $\mathrm{pM1}$ & 1 & 3 & 0.306 & 2 & 2 & 0.921 \\
\hline Diameter* & & $15-65(30)$ & $10-90(27)$ & 0.156 & $18-75$ & $10-90(24)$ & 0.002 \\
\hline Ki-67 \%* & & $0-54.2(17.6)$ & $0-47.2(16.6)$ & 0.697 & $0-54.2(18.3)$ & $0-47.2(13.4)$ & 0.127 \\
\hline \multirow[t]{2}{*}{ ERa } & positive & 15 & 9 & 0.244 & 14 & 10 & 0.641 \\
\hline & negative & 37 & 42 & & 40 & 39 & \\
\hline \multirow[t]{2}{*}{ ERß } & positive & 49 & 43 & 0.097 & 50 & 42 & 0.257 \\
\hline & negative & 3 & 8 & & 4 & 7 & \\
\hline \multirow[t]{2}{*}{ Aromatase } & positive & 47 & 39 & 0.057 & 47 & 39 & 0.309 \\
\hline & negative & 5 & 12 & & 7 & 10 & \\
\hline
\end{tabular}

Statistical analysis was conducted by Fisher exact test, Wilcoxon rank sum test, and Pearson $\chi^{2}$ test.

* Data were continuous variables and the median with minimum-maximum values were presented.

inhibited by $17 \beta$ HSD1 siRNA 2 transfection, $(p=<0.0001)$ (Figure 3f).

\section{Discussion}

In this study, we performed IHC analysis in 103 NSCLCs for evaluating the expression of 17ßHSD1 and 17ßHSD2 enzymes in NSCLC tissues. Both 17ßHSD1 and $17 \beta$ HSD2 were immunolocalized in the cytoplasm of carcinoma cells (Figure 1 Normal bronchial epithelial cells detected in the specimens were only occasionally weakly positive for either 17ßHSD1 and/or 17ßHSD2, suggesting a possible up-regulation of these enzymes in carcinoma cells. The majority of NSCLC cases examined in this study were positive for either 17ßHSD1 (85\%) and/or 17ßHSD2 (95\%) (Table 1). A relatively high number of NSCLC cases examined also demonstrated aromatase immunoreactivity (Table 1 ) as reported in many previous studies [7]. Intratumoral expression of estrogen producing enzymes i.e. aromatase, $17 \beta \mathrm{HSD} 1$ and $17 \beta H S D 2$, all indicated that biologically active estrogens are actively synthesized either via aromatase and/or $17 \beta$ HSDs pathway in NSCLC patients.

It is also true that $17 \beta \mathrm{HSD} 1$ and $17 \beta \mathrm{HSD} 2$ immunoreactivity was very heterogeneous in NSCLC cases (Figure 1). Therefore, based on relative immunointensity of either $17 \beta$ HSD1 and/or 2 in cytoplasm of the tumor cells, the cases were tentatively sub-classified as low (negative or weakly positive) and high (moderately/strongly positive) as previously reported in breast cancer [18]. In breast cancer cases, the status of $17 \beta$ HSD1 immunoreactivity in carcinoma cells was reported to be significantly correlated with that of ER and PgR, suggesting that E2, synthesized by $17 \beta H S D 1$ in carcinoma cells may act on these cells locally [18]. However, in our present study of lung cancer, a 


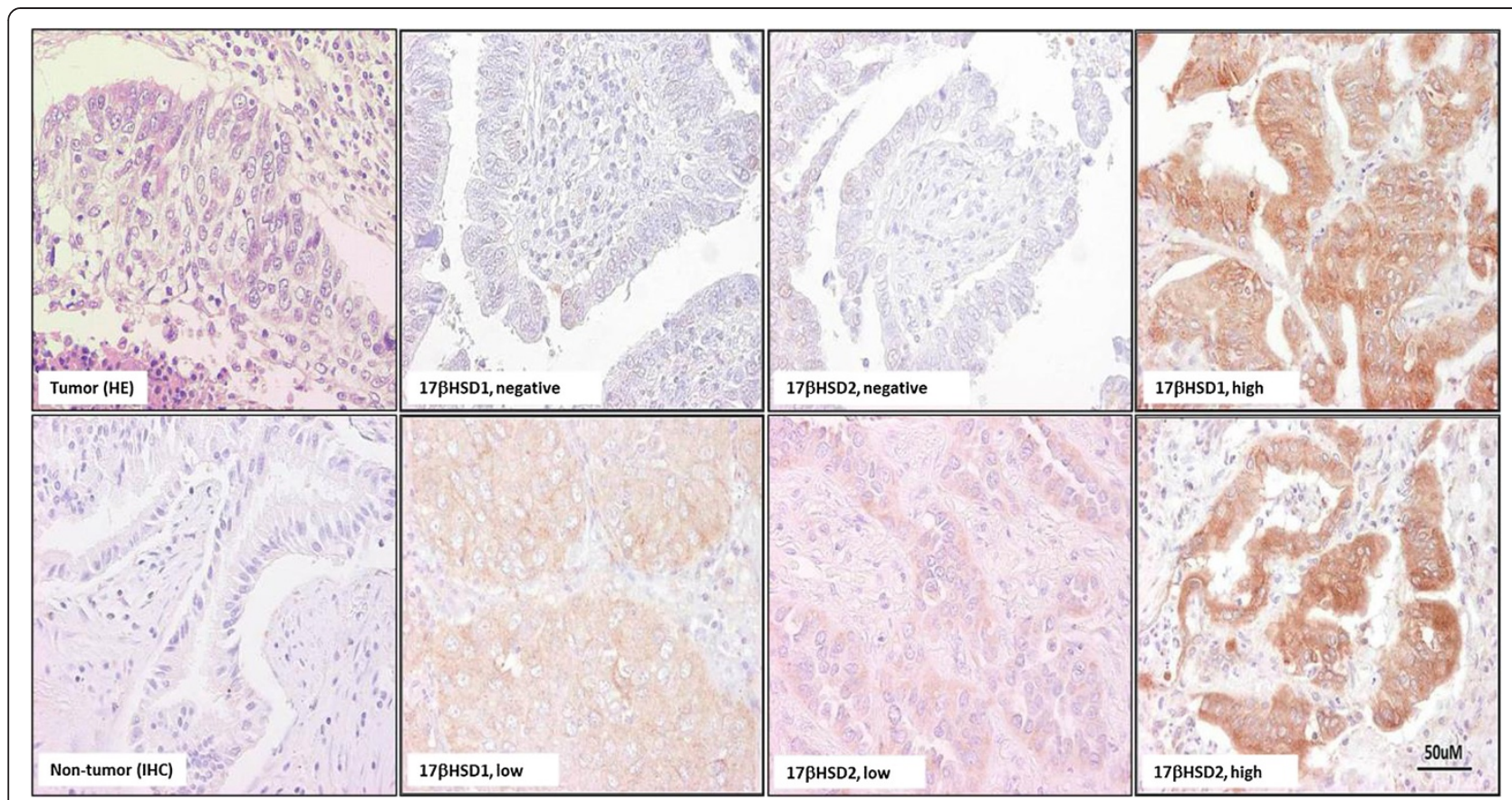

Figure 1 Representative illustrations of immunohistochemistry of $17 \beta H S D 1$ and $17 \beta H S D 2$ in cases of NSCLCs. Immunoreactivity was detected in the cytoplasm with varying intensity patterns, i.e. no staining, low staining and high staining.

relatively high immunoreactivity status of $17 \beta \mathrm{HSD} 1$ tended to be positively associated with $\operatorname{ER} \beta(p=0.097)$, aromatase $(p=0.057)$ and tumor stage $(p=0.055)$ (Table 2$)$, although that of $17 \beta$ HSD2 was not associated with either ER $\beta$ $(p=0.257)$ and/or aromatase status $(p=0.309)$ (Table 2). In addition, the status of ER $\alpha$ immunoreactivity was by no means associated with either 17ßHSD1 and/or 17ßHSD2 statuses (Table 2), suggesting a more pronounced association between ER $\beta$ and 17 $\beta$ HSD pathway. These findings also suggest a potential interaction between intratumoral aromatase and $17 \beta \mathrm{HSD}$ pathways signaling in lung carcinoma cells. However, a high $17 \beta$ HSD2 status was significantly associated with histological grade $(p=0.031)$, tumor stage $(p=0.004)$, T factor of TMN classification $(p=0.010)$, maximum tumor diameter; $(p=0.002)$ and also tended to be associated with $\mathrm{N}$ factor of TMN classification $(p=0.065)$, (Table 2). These results indicated that 17ßHSD2 may also play an important role in regulating lung cancer biology.

It then becomes important to evaluate the contribution of $17 \beta \mathrm{HSD}$ pathway in NSCLC patient towards an availability of intratumoral estrogens i.e. E2 and E1. In this study, intratumoral E1 was significantly higher in lung carcinoma tissue when compared to non-neoplastic tissue of the same NSCLC patients (Figure 2a). In addition, a high immmunointensity status of 17ßHSD1 was associated with lower intratumoral E1 concentration and that of $17 \beta \mathrm{HSD} 2$ with higher intratumral E1 concentrations (Figure 2c,d). There were, however, no significant differences in intratumoral E2 concentration among patients having either high or low immmunointensity status of $17 \beta \mathrm{HSD} 1$ or 2 (data not shown). These results indicated that both $17 \beta$ HSD1 and 17ßHSD2 maintained a constant intratumoral E2 concentration equilibrium state by making use of available E2 and E1 in situ. Therefore, it is important to analyze whether these enzymes; i.e. 17ßHSD1 and 17ßHSD2, contribute to the intratumoarl E2/E1 ratio in NSCLC cells or not. A high E2/E1 ratio was reported to be positively correlated with the proliferation of estrogen dependent breast carcinoma cells and its reduction is also considered to be an effective mean of facilitating breast cancer therapy [22]. In this study, a higher intratumoral E2/E1 ratio was significantly associated with a high immmunoreactivity status of $17 \beta$ HSD1 than that detected in patients with a low or negative $17 \beta$ HSD1 status $(p=0.028)$, (Figure $2 \mathrm{e})$. These results demonstrated that intratumoral $17 \beta$ HSD1 is also important for determining the E2/E1 ratio in lung carcinoma cells as in breast cancer patients and targeting $17 \beta$ HSD1 could possibly confer therapeutic benefits to these estrogen dependent lung carcinoma patients.

In this study, among 17ßHSD1 and 17ßHSD2 double positive cases (85 cases), both 17ßHSD1 and 17ßHSD2 were significantly correlated with each other $(p=0.014)$. In addition, the absence of $17 \beta$ HSD1 in tumor cells was 
(a)

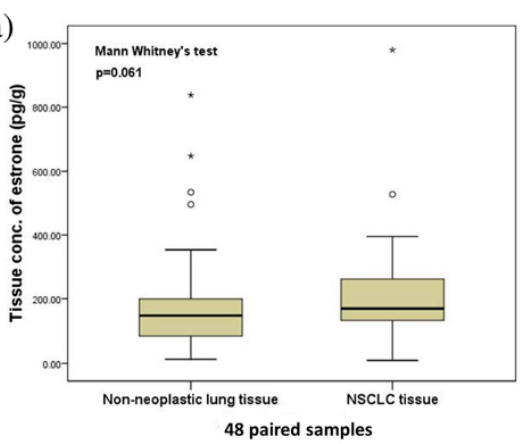

(b)

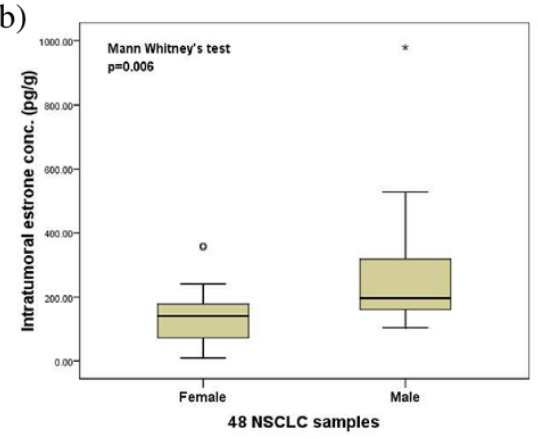

(c)

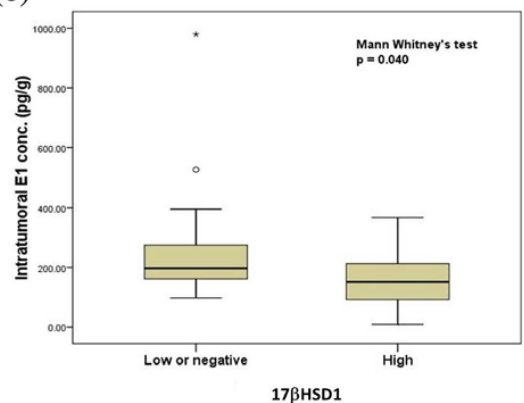

(d)

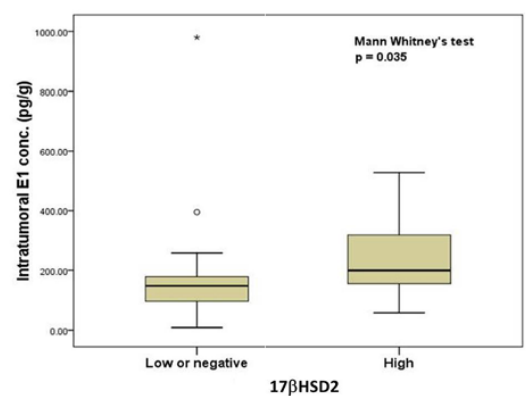

(e)

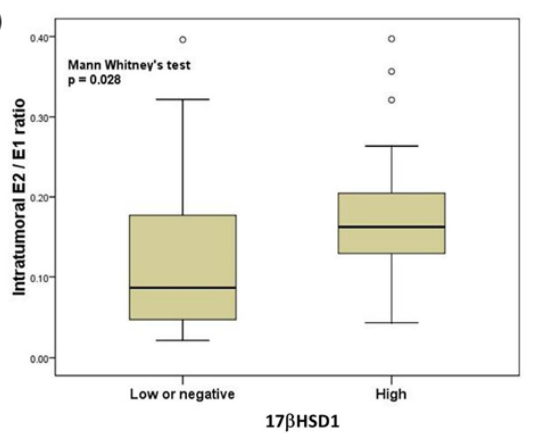

(f)

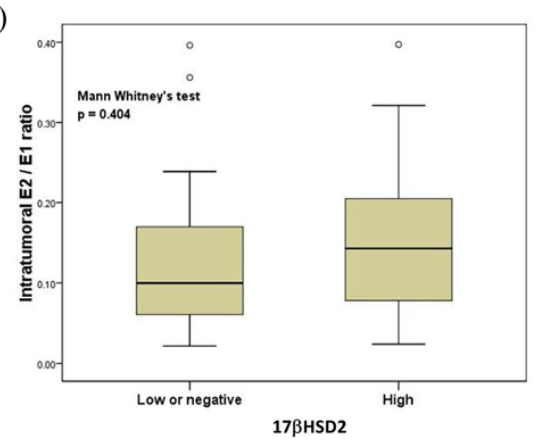

(g)

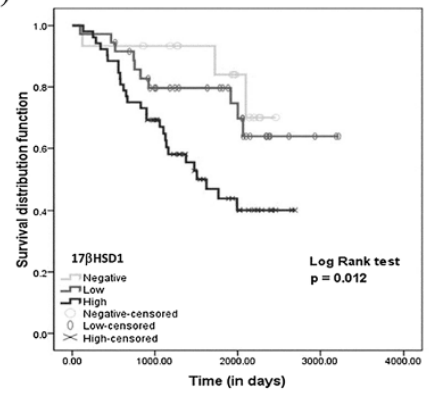

(h)

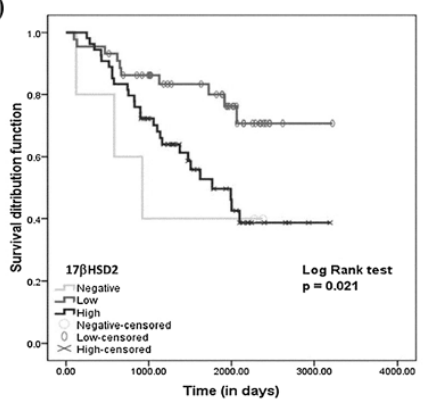

Figure 2 Intratumoral estrogens concentration and overall survival in NSCLC patients. (a) Intratumoral concentration of estrone in 48 NSCLCS and corresponding non-neoplastic lung tissues. (b) Intratumoral concentration of E1 in male and female NSCLCs. Association between intratumoral E1 concentration in 49 NSCLCs, (c) either with 17ßHSD1 or (d) with 17ßHSD2 enzymes. Association between intratumoral E2/E1 concentration in 49 NSCLCs, (e) either with $17 \beta H S D 1$ or (f) with 17ßHSD2 enzymes. The grouped data are represented as box plots. The median value is shown by a horizontal line in the box plot and the box denotes the 75th (upper margin) and 25th percentiles of the values (lower margin). Kaplan-Meier survival curves in 103 NSCLC patients, (g) according to 17ßHSD1 immunoreactivity; negative vs. low vs. high and (h) according to $17 \beta$ HSD2 immunoreactivity; negative vs. low vs. high. 
Table 3 Univariate and multivariate analyses for clinical outcome in 103 NSCLC patients

\begin{tabular}{|c|c|c|c|}
\hline \multirow[t]{2}{*}{ Variables } & \multicolumn{2}{|c|}{ Overall survival } & \multirow{2}{*}{$\begin{array}{c}\text { Hazard ratio } \\
(95 \% \mathrm{Cl})\end{array}$} \\
\hline & Univariate & Multivariate & \\
\hline SEX & $0.010^{*}$ & 0.039 & $2.22(.90-5.49)$ \\
\hline Histology & 0.508 & - & - \\
\hline Stage (I + II vs. III +IV) & $<0.0001^{*}$ & 0.041 & $3.97(1.05-15.02)$ \\
\hline pT & $<0.0001^{*}$ & 0.042 & - \\
\hline $\mathrm{pN}$ & $<0.0001^{*}$ & 0.054 & - \\
\hline pM & 0.585 & - & - \\
\hline Diameter ( $\geq 30$ mm vs. <30mm) & $0.002^{*}$ & 0.001 & $6.53(2.14-19.86)$ \\
\hline Ki-67 labeling ( $\geq 10 \%$ vs. < 10\%) & $0.010^{*}$ & 0.284 & $1.76(0.62-4.98)$ \\
\hline 17ßHSD1 (high vs. low/negative) & $0.003^{*}$ & 0.007 & $2.83(1.31-6.09)$ \\
\hline 17ßHSD2 (high vs. low/negative) & $0.023^{*}$ & 0.286 & $0.62(0.26-1.48)$ \\
\hline ERa expression & 0.599 & - & - \\
\hline ER $\beta$ expression & 0.570 & - & - \\
\hline Aromatase expression & 0.639 & - & - \\
\hline
\end{tabular}

*Data were considered significant in the univariate analyses, and were examined in the multivariate analyses.

significantly associated with better overall survival $(p=0.012)$ (Figure $2 \mathrm{~g}$ ) whereas the absence of $17 \beta \mathrm{HSD} 2$ with poorer overall survival of the patients examined $(p=0.021)$, (Figure $2 \mathrm{~h})$. A high immmunoereactivity status of either 17ßHSD1 $(p=0.012)$ and/or 17ßHSD2 $(p=0.021)$ was also significantly associated with poorer overall survival when compared to lower statuses (Figure 2g,h). E2 is well-known to stimulate breast and endometrial carcinoma development. However, high doses of E2 are also well known to induce regression of hormonedependent breast cancer in postmenopausal women and cause apoptosis of carcinoma cells [23]. Therefore, 17 HSD2 in NSCLC patients may play a role in protecting lung carcinoma cells from excessive stimulation of E2 by inactivation of potent E2 to inactive E1 and maintaining equilibrium status of constant E2 supply. Therefore, both $17 \beta$ HSD1 and 17ßHSD2 may work in tandem in order to maintain an equilibrium state of constant E2 supply in NSCLC tumor microenvironment. A multivariate regression analyses further demonstrated that only high $17 \beta \mathrm{HSD} 1$ status $(\mathrm{HR}=2.83, p=0.007)$ and not high $17 \beta \mathrm{HSD} 2(p=0.286)$ status was an independent prognostic factor (Table 3). These data clearly demonstrated the prognostic significance of $17 \beta \mathrm{HSD}$ pathways in estrogen dependent NSCLC patients. In addition, in this study clinical impact of $17 \beta$ HSD1 was much higher than that of ER $\beta$ (Table 3) suggesting that E2 may also have some other important functions besides ER $\beta$ mediated actions in NSCLCs, as suggested by earlier studies in breast cancer [24]. However, further investigations are definitely required for better clarifications.

Earlier studies demonstrated both A549 and LK87 cells as estrogen dependent NSCLC cell lines expressing aromatase [25,26]. Both of these cell lines expressed higher 17ßHSD1 mRNA level when compared to $17 \beta \mathrm{HSD} 2$ suggesting a more pronounced role of $17 \beta$ HSD1 in these NSCLC cells (Figure 3a,b). This $17 \beta$ HSD1 activity resulted in significantly higher E2 production (5-fold) when compared to aromatase activity in both A549 and LK87 cells $(p<0.0001)$ (Figure 3c). This difference could be due to a higher 17ßHSD1 level when compared to aromatase in these NSCLC cell lines [25]. We observed an increment of both 17ßHSD1 following AI therapy in these NSCLC cell lines suggesting a possible emergence of $17 \beta$ HSD pathway, (Figure 3d). This increment may represent a possible adaptation of carcinoma cells in response to intratumoral estrogen depletion, in lung cancer cells. We have recently demonstrated a similar increment of $17 \beta H S D 1$ following aromatase inhibitor (exemestane) treatment in the group associated with decreased Ki67 labeling index or clinical responders in breast cancer patients [27]. This result also suggests that $17 \beta$ HSD enzymes may represent as a potent marker for response to aromatase inhibitor therapy in the lung carcinoma, but it awaits further examinations. Finally, E1 treatment stimulated cell proliferation in both cell lines above which was significantly inhibited by 17ßHSD1 siRNA 2 transfection, $(p<0.0001)$ (Figure 3f).

\section{Conclusion}

These results all suggested that in addition to intratumoral production via aromatase pathway, $17 \beta \mathrm{HSD} 1$ is active and contributes to tumor progression of estrogen dependent NSCLC cells by making use of available intratumoral E1. Therefore, potential endocrine therapy targeting 17ßHSD1 may translate into therapeutic benefits to estrogen 


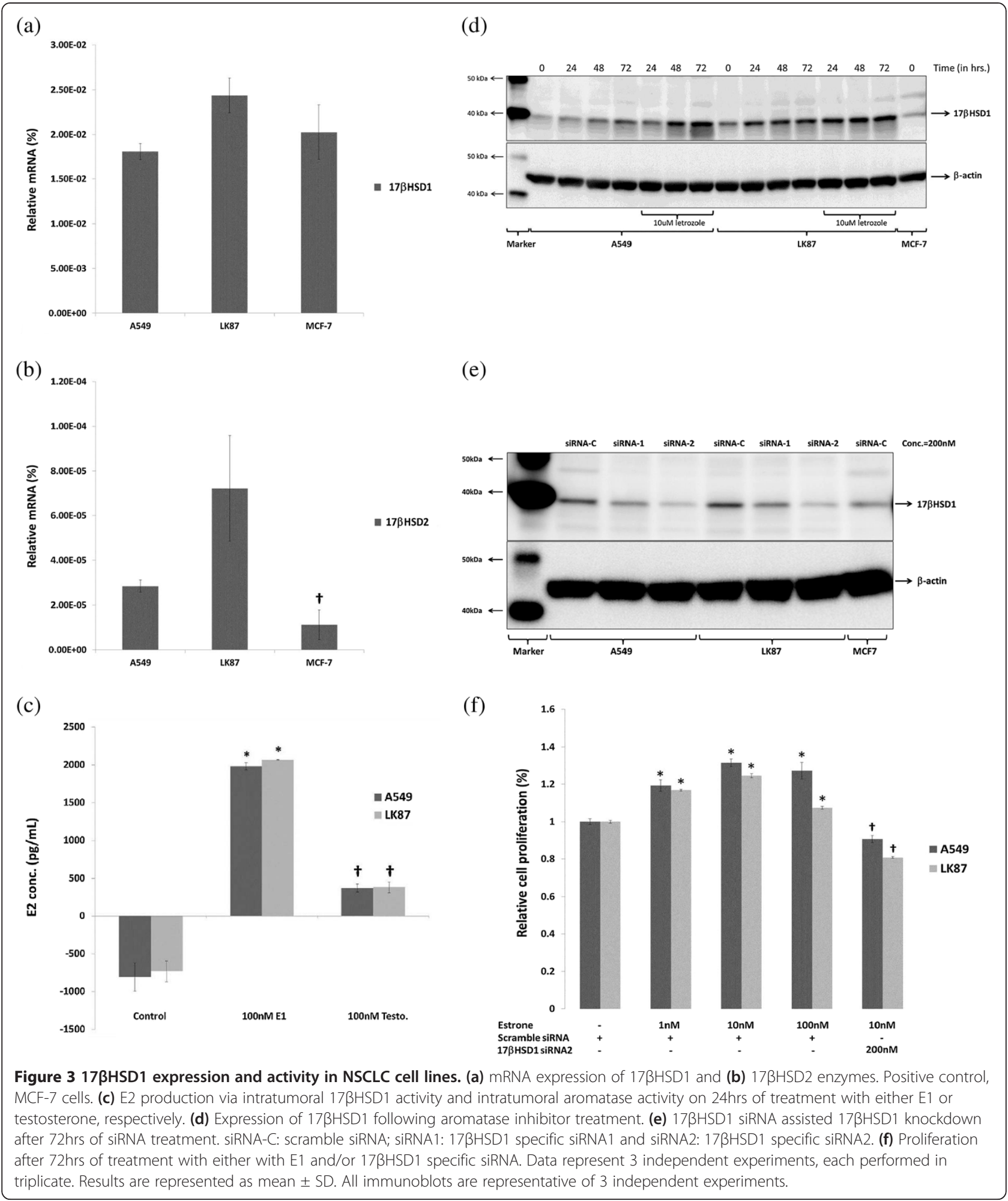

dependent NSCLC patients. Therefore, similar to estrogen dependent breast cancer patients, 17ßHSD1 inhibitors either alone or in combination with aromatase inhibitors may represent a novel approach for treating estrogen dependent lung cancer patients. It is also important to note that, in addition to $17 \beta \mathrm{HSD} 1$ and $17 \beta \mathrm{HSD} 2$, other sub-types of $17 \beta H S D$ s were also reported to be implicated in various hormone dependent carcinomas [28]. These 
$17 \beta$ HSD subtypes may therefore, be reasonably be postulated to play important roles in hormone dependent human lung cancer patients. However, further investigations are definitely required for clarifications.

\section{Additional files}

Additional file 1: The primary antibodies used in this study were as follows: (a) anti-ERß (1:50; clone 14C8; GeneTex). (b) anti-aromatase (1:3000; clone \#677/H7, provided by Novartis) [16]. (c) anti-ERa?(1:50; clone 6F11; Novocastra). (d) anti-173HSD1 (1:400; clone 2E5; Abnova). (e) anti-17ßHSD2 (1:200; Proteintech). (f) anti-Ki-67 (1:100; clone MIB1, DakoCytomation).

Additional file 2: The primer sequences used in this study were as follows. (a) 17BHSD1: (NM_000413; forward: 1,290-1,310 and reverse: 1,604-1,623). (b)17ßHSD2: (NM_002153; forward: 797-816 and reverse: 971-989). (c) RPL13A : (NM_012423; forward: 487-509 and reverse: 588-612).

Additional file 3: The sense and antisense sequences of the two $17 \beta H S D 1$ siRNAs used in this study were as follows. (a) 17BHSD1 siRNA 1: Sense sequence (5'-3'); GCCUUUCAAUGACGUUUAU [dT][dT], Anti-sense sequence (3'-5'); AUAAACGUCAUUGAAAGGC [dT][dT]. (b) 17BHSD1 siRNA 2: Sense sequence (5'-3'); CCACAGCAAGCAAGUCUUU $[\mathrm{d} T][\mathrm{dT}]$, Anti-sense sequence $\left(3^{\prime}-5^{\prime}\right) ;$ AAAGCAUUGCUUGCUGUGG $[\mathrm{d} T][\mathrm{dT}]$.

\section{Competing interests}

The authors declare that they have no competing interests.

\section{Authors' contributions \\ MKV designed the study and wrote the manuscript. SS and TK collected the samples and provided clinical data. MKV and TS evaluated the immunohistochemical stains. HN contributed the intratumoral E2 concentration data. MKV performed the IHC, LC-MS, Real time PCR analysis, ELISA assay and siRNA transfections, Cell proliferation assay and Immunoblotting. MKV statistically analyzed and interpreted the data. YM, KA and $\mathrm{HS}$ contributed to the writing of the manuscript. All authors read and approved the final manuscript.}

\section{Acknowledgements}

We thank Biomedical Research Core of Tohoku University Graduate School of Medicine for technical support.

\section{Author details}

'Department of Pathology, Tohoku University Graduate School of Medicine, Sendai, Japan. ${ }^{2}$ Department of Dentistry, Tohoku University Graduate School of Dentistry, Sendai, Japan. ${ }^{3}$ Department of Pathology and Histotechnology, Tohoku University Graduate School of Health Sciences, Sendai, Japan. ${ }^{4}$ Department of Thoracic Surgery, Institute of Development, Aging and Cancer, Tohoku University, Sendai, Japan. ${ }^{5}$ Department of Thoracic Surgery, Ishinomaki Red Cross hospital, Ishinomaki, Japan. ${ }^{6}$ Present address: The Jackson Laboratory, Bar Harbor, ME 04609 USA.

Received: 15 March 2013 Accepted: 27 June 2013

Published: 9 July 2013

\section{References}

1. Jemal A, Siegel R, Ward E: Cancer statistics. CA Cancer J Clin 2008, 58:71-96.

2. Thun MJ, Henley SJ, Burns D, Jemal A, Shanks TG, Calle EE: Lung cancer death rates in lifelong nonsmokers. J Natl Cancer Inst 2006, 98:691-699.

3. Hershberger PA, Vasquez AC, Kanterewicz B, Land S, Siegfried JM, Nichols M: Regulation of endogenous gene expression in human non-small cell lung cancer cells by estrogen receptor ligands. Cancer Res 2005, 65:1598-1605.

4. Verma MK, Miki Y, Sasano H: Sex steroid receptors in human lung diseases. J Steroid Biochem Mol Biol 2011, 127:216-222.

5. Hershberger PA, Stabile LP, Kanterewicz B, Rothstein ME, Gubish CT, Land S, Shuai Y, Siegfried JM, Nichols M: Estrogen receptor beta (ER $\beta$ ) subtypespecific ligands increase transcription, p44/p42 mitogen activated protein kinase (MAPK) activation and growth in human non-small cell lung cancer cells. J Steroid Biochem Mol Biol 2009, 116:102-109.

6. Ross H, Oldham FB, Bandstra B, Sandalic L, Bianco J, Bonomi P, Singer JW: Serum-free estradiol (E2) levels are prognostic in men with chemotherapy-naïve advanced non-small cell lung cancer and performance status (PS) 2 [abstract]. J Clin Oncol (Meeting Abstr) 2007, 25:7683-7683

7. Verma MK, Miki Y, Sasano H: Aromatase in human lung carcinoma. Steroids 2011, 76:759-764

8. Weinberg OK, Marquez-Garban DC, Fishbein MC, Fishbein MC, Goodglick L, Garban HJ, Dubinett SM, Pietras RJ: Aromatase inhibitors in human lung cancer therapy. Cancer Res 2005, 65:11287-11291.

9. ClinicalTrial.gov Identifier; NCT00932152: University of Pittsburgh, PA, USA: Fulvestrant and Anastrozole as Consolidation Therapy in Postmenopausal Women With Advanced Non-small Cell Lung Cancer; 2009. Available from: July 1, 2009 at http://clinicaltrials.gov/ct2/show/record/NCT00932152.

10. Nagasaki S, Miki Y, Akahira J, Suzuki T, Sasano H: 17beta-hydroxysteroid dehydrogenases in human breast cancer. Ann N Y Acad Sci 2009, 1155:25-32.

11. Oster A, Hinsberger S, Werth R, Marchais-Oberwinkler S, Frotscher M, Hartmann RW: Bicyclic substituted hydroxyphenylmethanones as novel inhibitors of $17 \beta$-hydroxysteroid dehydrogenase type 1 (17 $\beta$-HSD1) for the treatment of estrogen-dependent diseases. J Med Chem 2010, 53:8176-8186.

12. Marchais-Oberwinkler S, Wetzel M, Ziegler E, Kruchten P, Werth R, Henn C, Hartmann RW, Frotscher M: New drug-like hydroxyphenylnaphthol steroidomimetics as potent and selective 17ß-hydroxysteroid dehydrogenase type 1 inhibitors for the treatment of estrogendependent diseases. J Med Chem 2011, 54:534-547.

13. Starčević $S$, Kocbek P, Hribar G, Rižner TL, Gobec S: Biochemical and biological evaluation of novel potent coumarin inhibitor of $17 \beta-H S D$ type 1. Chem Biol Interact 2011, 191:60-65.

14. Sasano H, Anderson TJ, Silverberg SG, Santen RJ, Conway M, Edwards DP, Krause A, Bhatnagar AS, Evans DB, Miller WR: The validation of new aromatase monoclonal antibodies for immunohistochemistry-a correlation with biochemical activities in 46 cases of breast cancer. J Steroid Biochem Mol Biol 2005, 95:35-39.

15. Skov BG, Fischer BM, Pappot H: Oestrogen receptor beta over expression in males with non-small cell lung cancer is associated with better survival. Lung Cancer 2008, 59:88-94.

16. Ishibashi H, Suzuki T, Suzuki S, Niikawa H, Lu L, Miki Y, Moriya T, Hayashi S, Handa M, Kondo T, Sasano H: Progesterone receptor in non-small cell lung cancer-a potent prognostic factor and possible target for endocrine therapy. Cancer Res 2005, 65:6450-6458.

17. Suzuki T, Miki Y, Moriya T, Niikawa H, Lu L, Miki Y, Moriya T, Hayashi S, Handa M, Kondo T, Sasano H: 5Alpha-reductase type 1 and aromatase in breast carcinoma as regulators of in situ androgen production. Int $J$ Cancer 2007, 120:285-891.

18. Poutanen M, Isomaa V, Lehto VP, Vihko R: Immunohistochemical analysis of 17- $\beta$ hydroxysteroid dehydrogenase in benign and malignant human breast tissue. Int I Cancer 1992, 50:386-390.

19. Niikawa H, Suzuki T, Suzuki S, Nagasaki S, Akahira J, Honma S, Evans DB, Hayashi S, Kondo T, Sasano H: Intratumoral Estrogens and Estrogen receptors in Non-small cell lung carcinoma. Clin Cancer Res 2008 14:4417-4426.

20. Miki Y, Suzuki T, Tazawa C, Yamaguchi Y, Kitada K, Honma S, Moriya T, Hirakawa H, Evans DB, Hayashi S, Ohuchi N, Sasano H: Aromatase localization in human breast cancer tissues: possible interactions between intratumoral stromal and parenchymal cells. Cancer Res 2007 67:3945-354.

21. Verma MK, Miki Y, Abe K, Niikawa H, Sasano H: Cytoplasmic estrogen receptor $\beta$ as a potential marker in human non-small cell lung carcinoma. Expert Opinion Therapeutic Targets 2012, 16:S91-S102.

22. Aka JA, Mazumdar M, Chen CQ, Poirier D, Lin SX: 17beta-hydroxysteroid dehydrogenase type 1 stimulates breast cancer by dihydrotestosterone inactivation in addition to estradiol production. Mol Endocrinol 2010, 24:832-845

23. Song RX, Santen RJ: Apoptotic action of estrogen. Apoptosis 2003, 8:55-60.

24. Yue W, Wang JP, Li Y, Fan P, Liu G, Zhang N, Conaway M, Wang H, Korach KS, Bocchinfuso W: Effects of estrogen on breast cancer development: Role of estrogen receptor independent mechanisms. Int J Cancer 2010, 127:1748-1757. 
25. Verma MK, Miki Y, Abe K, Niikawa H, Nagasaki S, Suzuki S, Kondo T, Sasano $\mathrm{H}$ : Estrogen receptor beta and aromatase in lung carcinoma patients: gender dependent clinical outcome. Life Sciences 2012, 91:800-808.

26. Stabile LP, Lyker JS, Gubish CT, Zhang W, Grandis JR, Siegfried JM:

Combined targeting of the estrogen receptor and the epidermal growth factor receptor in non-small cell lung cancer shows enhanced antiproliferative effects. Cancer Res 2005, 65:1459-70.

27. Chanplakorn N, Chanplakorn P, Suzuki T, Ono K, Chan MS, Miki Y, Saji S, Ueno T, Toi M, Sasano H: Increased estrogen sulfatase (STS) and 17betahydroxysteroid dehydrogenase type 1(17beta-HSD1) following neoadjuvant aromatase inhibitor therapy in breast cancer patients. Breast Cancer Res Treat 2010, 120:639-648.

28. Rotinen M, Villar J, Encío I: Regulation of 17ß-hydroxysteroid dehydrogenases in cancer: regulating steroid receptor at pre-receptor stage. J Physiol Biochem 2012, 68:461-473.

doi:10.1186/1479-5876-11-167

Cite this article as: Verma et al.: Intratumoral localization and activity of $17 \beta$-hydroxysteroid dehydrogenase type 1 in non-small cell lung cancer: a potent prognostic factor. Journal of Translational Medicine 2013 11:167.

\section{Submit your next manuscript to BioMed Central and take full advantage of:}

- Convenient online submission

- Thorough peer review

- No space constraints or color figure charges

- Immediate publication on acceptance

- Inclusion in PubMed, CAS, Scopus and Google Scholar

- Research which is freely available for redistribution 